\title{
A REVIEW: ANTI-CANCER NATURAL PRODUCT DRUG DELIVERY SYSTEM DOSAGE FORM AND EVALUATION
}

\author{
RIZKA KHOIRUNNISA GUNTINA ${ }^{1}$, IYAN SOPYAN ${ }^{1,2}$, ADE ZUHROTUN ${ }^{3 *}$
}

\author{
1Department of Pharmaceutics and Pharmaceutical Technology, Faculty of Pharmacy, Universitas Padjajaran, Jatinangor, Indonesia \\ 45363, 2Center of Drug Development, Faculty of Pharmacy, Universitas Padjajaran, Jatinangor, Indonesia 45363, ${ }^{3}$ Department of \\ Biological Pharmacy, Faculty of Pharmacy, Universitas Padjajaran, Jatinangor, Indonesia 45363 \\ Email: ade.zuhrotun@unpad.ac.id
}

Received: 05 Aug 2021, Revised and Accepted: 11 Oct 2021

\begin{abstract}
A drug delivery system is a system in which a drug is released from a pharmaceutical dosage form to achieve the desired pharmacological effect. The system consists of conventional and new drug delivery systems. In the new drug delivery system, polymers are used as a matrix. The aim of this article is to find out and understand the formulation and evaluation of natural ingredients that have anticancer activity with different dosage forms and the basis for developing these dosages. Journal searches in this review came from primary data sources on the internet. Journal searches were carried out using a search engine such as Google Scholar, PubMed, and ScienceDirect. In recent years, natural products, such as extract, fraction, and isolate, are getting attention to help treat cancer. Because of their low solubility and bioavailability, the effectiveness tends to be lower than synthetic drugs. Therefore, a dosage form with a new drug delivery system was made to overcome the problem. The dosage forms commonly made are patch, suspension, powder, and emulsion with a new drug delivery system. To ensure the product that has been made met the requirements, they need to be evaluated with various methods like In vitro Study, morphology study, particle size study, and others. Cancer treatment using the natural product can be delivered through several dosage forms like patch, suspension, powder, and emulsion, with specific formulation and manufacturing methods based on several considerations such as natural ingredients properties, dosage form selection, excipient properties, and the purpose of the formulation. Dosage forms that has been made are then evaluated using several evaluation methods.
\end{abstract}

Keywords: Drug delivery system, Extract, Evaluation, Matrix

(C) 2021 The Authors. Published by Innovare Academic Sciences Pvt Ltd. Thisis an open access article under the CCBYlicense (https://creativecommons.org/licenses/by/4.0/) DOI: https://dx.doi.org/10.22159/ijap.2021.v13s4.43815 Journal homepage: https://innovareacademics.in/journals/index.php/ijap

\section{INTRODUCTION}

Drug delivery is a method or process of administering a drug compound to achieve a therapeutic concentration so as to produce the desired therapeutic effect on humans or animals [1]. A drug delivery system (DDS) is defined as a formulation or device that enables a therapeutic compound or drug to selectively reach its specific site of action without affecting normal or non-target tissues or cells [2].

In recent years, the development of natural product drug delivery systems has progressed significantly. Natural products consist of natural ingredients like extract, purified extract, fraction, and isolate. Natural ingredients have an important role in the discovery of new drugs, especially for the treatment of cancer and infectious diseases [3]. Natural ingredients, such as extracts, fractions, or isolates, have special characteristics compared to synthetic compounds. Natural ingredients tend to have greater molecular weights, more hydrogen bond acceptors and donors, and smaller partition coefficients or cLogP values, indicating higher hydrophilicity and higher molecular rigidity compared to synthetic compounds [4]. For natural ingredients to be made into certain dosage forms needed to be adjusted so that the drug can achieve their target effect. Extract with more than one natural compound will have larger molecular weight. Therefore, extract needed more adjustment than natural compound or isolate. Aside from that, dosage form selection also affects how the drug will work. So that dosage form and manufacturing method selection are crucial processes in developing a new natural product drug. With the increasing numbers of natural products with anticancer activity, the research to fully develop an anti-cancer natural product drug. Cancer treatment that is already established commonly causes several uncomfortable side effects from mild side effect to severe side effect. On the contrary, natural products with anti-cancer activity have lower side effect compared to synthetic anticancer drugs. Because of that, researches regarding anticancer natural product drug are rapidly developing.

In recent years, the research regarding natural drug delivery is mostly done to find suitable systems to deliver the drug to the target tissue. Therefore, a new drug delivery system is getting attention.
New drug delivery systems such as nanoparticles and microparticles are widely used as natural drug delivery systems. Drug bioavailability parameters have an important role in determining the success of a drug to pass through pharmacological phases such as biopharmaceuticals, pharmacokinetics, and pharmacodynamics [5]. In order to achieve maximum drug bioavailability, one of the important factors that can increase drug bioavailability is its solubility [6]. The particle size of the nanoparticles and microparticles can increase the solubility by increasing the surface area, thereby facilitating penetration into cell membranes, and can also provide a controlled release system with active and passive targeting [7]. Methods used to achieve this vary depending on the properties of natural ingredients, properties of the polymer used as a matrix, and what kind of dosage form will be made. Each method has advantages and disadvantages that need to be considered so that the product is suitable for the initial purpose.

Drug delivery systems can increase the effectiveness of various natural compounds to be able to reach cancer cells using various techniques. By reviewing the various dosages of natural ingredients with their delivery systems, we can find out the various current developments. This review was written to find out and understand the formulation and evaluation of natural ingredients that have anticancer activity with different dosage forms and the basis for developing these dosages.

\section{Method}

Articles used in this review articles writing were international journals. Journal searches came from primary data sources on the internet. Journal searches were carried out using a search engine such as Google Scholar, PubMed, and Science Direct with keywords of "Formulation", "Drug Delivery System", "Herbs", "Natural Products", "Extract", and "Cancer". The journal articles used were 40 journals obtained with a range of publication years 2012-2021 as shown in Graph 1 and 2.

\section{Drug delivery system}

A drug delivery system is a system that determines how a drug will be released from its dosage form. The selection of different drug 
delivery systems will provide different release results. The choice of the delivery system is generally based on the nature of the active substance used, the stability of the raw material in the dosage form, and the intended use of the drug. For each natural product like extract, fraction, or isolate to be made into a dosage form, they needed other excipients and went through manufacturing processes. Each different dosage form required a different excipient, matrix and method in the manufacturing process.

Depending on the target intended, natural products could be made into a patch, suspension, emulsion, and powder form. Other than that, it could also be made into other forms like micel or nanofiber. Because of its properties, several measures on the natural product treatment so that the natural product could be made into desired dosage form and achieve the target effect. Methods that can be used are variative depending on the dosage form selection and the desired delivery. Some of the manufacturing method that can be used to process the natural product into pharmaceutical dosage form are Thin Film Hydration (TFH), Emulsification, Solvent evaporation, Desolvation Method, High-Pressure Homogenization (HPH), Ultrasonication, and Solvent transfer method. Although the research for anticancer natural product drug delivery systems is mostly still tested in vitro and in vivo on animals, it is promising progress for the natural product drug development field.

\section{Patch dosage form}

A patch or transdermal drug delivery system can be defined as a self-contained dosage, which can deliver the drugs contained in it into the blood circulation system through the layer of skin it is attached to. Dispensing through this delivery system is very appropriate for drugs or compounds with low molecular weight and cannot withstand metabolism in the gastrointestinal tract or the first-pass effect [8]. In recent years, the use of this delivery system has been increasingly popular. This is because the main advantage of this delivery system is that it can avoid the gastrointestinal tract and pass through the first-pass effect, which can reduce drug bioavailability due to degradation. This makes the frequency of drug administration can be reduced and, therefore, can improve patient compliance. In addition, dosage with this system can be easily and quickly removed from the skin surface after usage [9]. A transdermal drug delivery system can deliver drugs into the blood circulation more conveniently and effectively. Thus, dispensing using this system tends to be preferred by patients [10]. In the manufacturing process of patch dosage, several different types of polymers are used depending on the type of natural material used as the active substance. In addition, an evaluation of the dosage is also carried out, as listed in table 1.

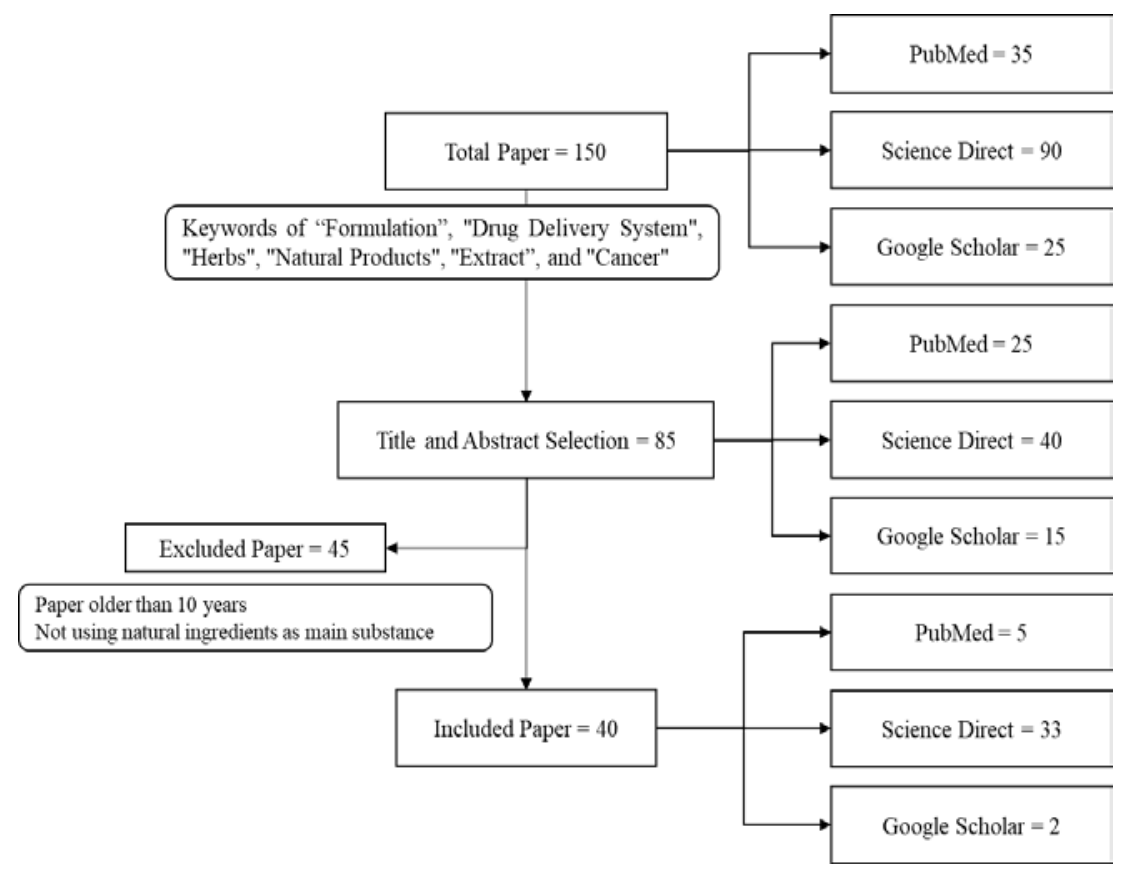

Fig. 1: Writing method flowchart

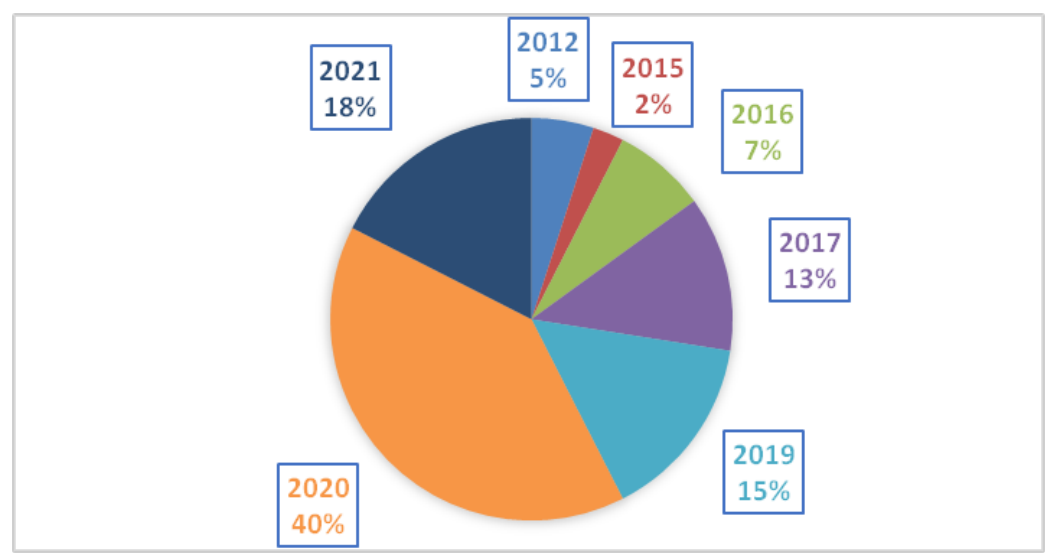

Fig. 2: Number of journal used each years 
Table 1: Dosage forms of natural patch medicines

\begin{tabular}{|c|c|c|c|c|}
\hline No & Extract & Matrix & Evaluation & Reference \\
\hline 1 & Hibiscus rosa sinensis & Carbopol-940 & Physicochemical evaluation, Weight uniformity, Patch thickness, Drug & [8] \\
\hline 2 & Hibiscus rosa sinensis & Pectin & content determination, Fold resistance, Moisture uptake percentage, & \\
\hline 3 & Hibiscus rosa sinensis & Sodium alginate & $\begin{array}{l}\text { Moisture content percentage, Surface } \mathrm{pH} \text { determination, Elongation } \\
\text { percentage, Tensile strength, Diffusion test }\end{array}$ & \\
\hline 4 & Curcuma longa & $\begin{array}{l}\text { Hydroxypropyl } \\
\text { methylcellulose (HPMC) }\end{array}$ & $\begin{array}{l}\text { Patch thickness, Drug content determination, Fold resistance, Moisture } \\
\text { uptake percentage, Moisture content percentage, Diffusion test }\end{array}$ & [9] \\
\hline 5 & Brassica nigra & Chitosan & $\begin{array}{l}\text { Organoleptic, Thickness, Weight uniformity, Fold resistance, Moisture, } \\
\text { Drug content, Diffusion test }\end{array}$ & {$[10]$} \\
\hline 6 & Nelumbo nucifera & PVA-HPMC & Moisture, Chemical evaluation, Thickness, Weight variation, Drug & {$[11]$} \\
\hline 7 & Nelumbo nucifera & PVA-PVP & content, Folding resistance & \\
\hline
\end{tabular}

In the patch dosage formulation, the polymer is used as a matrix. The use of polymers in the patch dosage aims to control drug release speed from the patch [12]. One of the polymers used is Carbopol. Carbopol is a synthetic polymer with a high molecular weight. Carbopol is a hydrophilic polymer [13]. Carbopol is safe and effective to use and does not cause sensitization. Carbopol also does not affect the biological activity of the active substance. So, Carbopol is good to be used as a matrix in patch dosage [14]. Manufacture of Hibiscus rosa sinensis patch using Carbopol as a polymer can provide good percent diffusion of Hibiscus rosa sinensis. In addition, the release can be restrained so that it can produce a dosage patch with a sustained release system [8].

Natural ingredients (extracts, fractions, isolates) that are suitable to be made as a patch are natural ingredients that undergo the firstpass effect or are unstable in the gastrointestinal tract. The patch dosage form was made to avoid the first-pass metabolism and consequent degradation that can reduce its bioavailability. One of the driving forces of the development of the patch is the increasing number of drugs that can be delivered to the systemic circulation in clinically effective concentration through the skin portal [8].

Patch dosage made with active substances from natural ingredients (extracts, fractions, isolates) needs to be evaluated. Evaluation of patch dosage aims to ensure that the patch made meets the requirements and can release the drug according to the original purpose of making the patch. Evaluations of patch dosage that are commonly carried out include evaluations of physicochemical, weight uniformity, patch thickness, moisture uptake, moisture content, folding resistance, determination of drug content, and diffusion test.

A method can be said to be successful when patches that are made are uniform in thickness and drug content. And also, the drug release profile of the patch that was made should fit to desired release rate. The patch should also have folding endurance so it would not break and maintain skin integrity when applied to the skin [11]. A good patch is said to have moisture uptake up to $15 \%$. This value will prevent the bulkiness of the film during usage [15]. It is also a suitable value to help protect the formulation from microbial contamination [11].

\section{Suspension dosage form}

Suspension dosage is a dosage form consisting of an insoluble drug substance in a fine form, dispersed in a carrier fluid with a heterogeneous system. The suspension consists of two phases. The outer phase is usually a liquid or semi-solid particle, and the inner phase consists of small, insoluble particles.

In general, many natural products are made in the form of suspension. This is because the suspension is an ideal dosage form for insoluble active substances, one of which is in the form of extracts, fractions, or isolates. In addition, most dosages of natural ingredients have an unpleasant taste. Thus, the manufacture of this dosage form can minimize these shortcomings.

Table 2: Dosage form of suspension natural medicines

\begin{tabular}{|c|c|c|c|c|c|}
\hline No & Extract & Matrix & Evaluation & Method & Reference \\
\hline 1 & Propolis & $\begin{array}{l}\text { Cholesterol } \\
\text {-tween } 80\end{array}$ & $\begin{array}{l}\text { Encapsulation efficiency, Particle size analysis, } \\
\text { DSC Analysis, FTIR Analysis, SEM. Analysis }\end{array}$ & Ether injection method & [16] \\
\hline 2 & Camellia sinensis & $\begin{array}{l}\text { Tween 40-Span } 40- \\
\text { Cholesterol }\end{array}$ & $\begin{array}{l}\text { Shape and morphology (SEM and TEM), Size } \\
\text { distribution, Surface tension, Encapsulation } \\
\text { efficiency, Release test, Stability test }\end{array}$ & $\begin{array}{l}\text { Thin-film hydration } \\
\text { (TFH) }\end{array}$ & [17] \\
\hline 3 & Aloe-emodin extract & $\begin{array}{l}\text { Poloxamer } 188- \\
\text { Poloxamer } 407\end{array}$ & $\begin{array}{l}\text { Mean diameter and zeta potential, DSC, TEM, } \\
\text { Entrapment Efficiency, In vitro release assay }\end{array}$ & $\begin{array}{l}\text { High Pressure } \\
\text { Homogenization }(\mathrm{HPH})\end{array}$ & [18] \\
\hline 4 & Black bean extract & Exosome & Exosome uptake & Electroporation & [19] \\
\hline 5 & $\begin{array}{l}\text { Frankincense and } \\
\text { myrrh essential oils } \\
\text { (FMO) }\end{array}$ & Compritol 888 ATO & $\begin{array}{l}\text { Particle size, Zeta potential, Encapsulation } \\
\text { efficiency, TEM, DSC, XRD, In vitro evaporation } \\
\text { release }\end{array}$ & $\begin{array}{l}\text { High Pressure } \\
\text { Homogenization }(\mathrm{HPH})\end{array}$ & {$[20]$} \\
\hline 6 & $\begin{array}{l}\text { Angelica gigas Nakai } \\
\text { extract }\end{array}$ & - & $\begin{array}{l}\text { Entrapment efficiency, In vitro stability, In vitro } \\
\text { release test }\end{array}$ & $\begin{array}{l}\text { Emulsification+Solvent } \\
\text { evaporation }\end{array}$ & {$[21]$} \\
\hline 7 & Quercetin & Chitosan & $\begin{array}{l}\text { Zeta potential, Particle Distribution, } \\
\text { Morphology, FT-IR, DSC, TGA, Drug Loading, } \\
\text { Encapsulation efficiency }\end{array}$ & $\begin{array}{l}\text { Ionic cross-linking } \\
\text { Technique }\end{array}$ & {$[22]$} \\
\hline 8 & $\begin{array}{l}\text { Alpinia officinarum } \\
\text { Hance rhizome } \\
\text { (Galangin) }\end{array}$ & Niosome & $\begin{array}{l}\text { EE, Morphology, Vesicle Size, PDI, Zeta } \\
\text { Potential, FT-IR, DSC, In vitro Release, Vesicle } \\
\text { Stability }\end{array}$ & $\begin{array}{l}\text { Reverse-phase } \\
\text { evaporation (REV) } \\
\text { Method }\end{array}$ & [23] \\
\hline 9 & Curcumin & $\begin{array}{l}\text { HER2 Aptamer } \\
\text { decorated Human } \\
\text { Serum Albumin (HAS) }\end{array}$ & $\begin{array}{l}\text { Morphology, Particle size and particle size } \\
\text { distribution, DL and EE, Hydrodynamic } \\
\text { diameter, Zeta potential, In vitro Release }\end{array}$ & Desolvation Method & {$[24]$} \\
\hline 10 & $\begin{array}{l}\text { Allium sativum L. leaf } \\
\text { aqueous extract }\end{array}$ & Gold & FT-IR, TEM, FE-SEM & & {$[25]$} \\
\hline 11 & $\begin{array}{l}\text { Artemisia absinthium } \\
\text { extract }\end{array}$ & $\begin{array}{l}\text { N-isopropylacrylamide } \\
\text { (NIPAAM)+VP+AA }\end{array}$ & Morphology, Particle size, PDI, FT-IR & $\begin{array}{l}\text { Free radicals } \\
\text { Mechanisms }\end{array}$ & {$[26]$} \\
\hline
\end{tabular}


Natural dosages generally have low solubility and bioavailability. So, a new delivery system is created to increase its solubility and bioavailability in the body by making microparticle and nanoparticle systems. So, with a smaller size, the surface area of the drug particles is getting bigger, and the solubility of the drug can be increased. Moreover, it can also be made as a controlled delivery system such as a targeted drug. With this system, the natural drugs can be directly delivered to the site of action. Therefore, the effectiveness of these drugs can be increased and also reduce the risk of drug release in unwanted organs, which can reduce drug concentrations at the target site or organ.

In the manufacture of suspension dosage with new drug delivery systems, several types of extracts are used. Several different types of polymers are used in the manufacturing process depending on the type of natural material used as the active substance. In addition, an evaluation of the preparations was also carried out, as listed in table 2 .

The preparation that was chosen in these researches are as listed in table 2. Those methods were selected based on the properties of the natural ingredients and matrix used in the manufacturing process of the dosage form. Because of the unpleasant taste of the natural ingredients, suspension dosage form was found to be the most ideal dosage form to cover that up. Due to low solubility of the natural ingredients, these natural ingredients are made into nanoparticles or microparticles before they mere made into the pharmaceutical dosage form.

The evaluations of suspension in the form of nanoparticles or microparticles include the morphology evaluation with SEM and TEM, particle size analysis, zeta potential measurement, drug content, and encapsulation efficiency measurement. The other parameters are the analysis using DSC, FT-IR, and TGA; polydispersity index measurement (PDI); in vitro release test; hydrodynamic diameter measurement; and vesicle stability testing. Evaluations that have been done should meet the allowed value stated in local or international regulation for the dosage form is said to "meet the quality". Different value ranges will be applied to different tests. Dosage forms that meet the quality requirements are assured to be safe and effective. Therefore, a dosage form needed to be evaluated before being marketed and used to patients.

In the morphology evaluation, SEM and TEM are used to find out the particle in the dosage form. They are also used to see the uniformity of the shape and size. Because the natural ingredients are made into micro or nano-sized particles, it is important to measure the particle's size, zeta potential, and entrapment efficiency. These parameters show how the method was carried out successfully or not. The uniformity of particle size shows the method was successfull and the particles are distributed evenly. As for zeta potential, particles with zeta potential values more than $+30 \mathrm{mV}$ and less than $-30 \mathrm{mV}$ are considered highly dispersed and particles with zeta potential value between $+10 \mathrm{mV}$ and$10 \mathrm{mV}$ are considered neutral [27]. Entrapment efficiency shows the percentage of drug that is successfully entrapped into the micelle or nanoparticle. The greater the entrapment efficiency value, the more successful the method was carried out.

\section{Powder dosage form}

The powder is the most basic and most widely available dosage form in the pharmaceutical world. In addition, powder dosage is easy to produce, so that the costs required to produce powder are relatively lower than other dosages. Powder dosage is a mixture of drugs or medicinal ingredients that have been pulverized. The intended use of these dosages includes both oral and topical dosages.

Along with the development of the use of natural ingredients as raw materials or active substances from pharmaceutical dosages, there are also more methods to overcome the main shortcomings of the active substances of natural ingredients. The low solubility and bioavailability of a natural ingredient limit the effectiveness of the dosages of these natural ingredients. Therefore, several new methods are used to minimize this effect. One of them is using a matrix system. By using this system, the problem of natural ingredients solubility dosage can be solved. In addition, its effectiveness and bioavailability can also be increased due to the micro/nanoencapsulation system used [28].

Table 3: Dosage form of natural powder medicines

\begin{tabular}{|c|c|c|c|c|c|}
\hline No & Extract & Matrix & Evaluation & Method & Reference \\
\hline 1 & $\begin{array}{l}\text { BRM270 } \\
\text { phytocomposite }\end{array}$ & - & $\begin{array}{l}\text { UV-Vis, FE-SEM, HR-TEM, FT-IR, DLS, Particle } \\
\text { Size, Particle Distribution, Average Diameter, } \\
\text { Physical-Chemical Stability, HPLC }\end{array}$ & $\begin{array}{l}\text { Mechanical milling } \\
\text { Method }\end{array}$ & [32] \\
\hline 2 & $\begin{array}{l}\text { Curcumae } \\
\text { kwangsiensis Folium } \\
\text { (Leaf) aqueous extract }\end{array}$ & Gold $(\mathrm{Au})$ & $\begin{array}{l}\text { Morphology, Particle size, Fractal dimensions, } \\
\text { Crystallinity, Surface area }\end{array}$ & Green Synthesis & {$[33]$} \\
\hline 3 & Honokiol & $\begin{array}{l}\text { PEG-PLGA diblock } \\
\text { copolymers }\end{array}$ & $\begin{array}{l}\text { Mean particle size, Particle size distribution, Zeta } \\
\text { potential, Morphology, Polydispersity Index PDI, } \\
\text { Encapsulation efficiency, In vitro Release, In vitro } \\
\text { Stability }\end{array}$ & $\begin{array}{l}\text { Nanoprecipitation } \\
\text { Method }\end{array}$ & {$[31]$} \\
\hline 4 & Poria cocos extract & Liposome & $\begin{array}{l}\text { Morphology, Diameter, Entrapment efficiency, } \\
\text { PDI, Release In vitro }\end{array}$ & & [34] \\
\hline 5 & BioPerine (Piperine) & $\begin{array}{l}\text { Chitosan-PEG coated } \\
\text { PLA hybrid }\end{array}$ & $\begin{array}{l}\text { EE, Morphology and particle size distribution, } \\
\text { Surface Chemistry, Chemical interaction, In vitro } \\
\text { Release, XRD }\end{array}$ & $\begin{array}{l}\text { oil-in-water }(\mathrm{O} / \mathrm{W}) \\
\text { single emulsion solvent } \\
\text { evaporation Method }\end{array}$ & [35] \\
\hline 6 & $\begin{array}{l}\text { Withania somnifera } \\
\text { extract (withaferin) }\end{array}$ & Niosome & $\begin{array}{l}\text { FT-IR, SEM Analysis, DSC Analysis, Particle Size, } \\
\text { EE, In vitro Dissolution }\end{array}$ & $\begin{array}{l}\text { reverse-phase } \\
\text { evaporation (REV) } \\
\text { Method }\end{array}$ & [36] \\
\hline 7 & $\begin{array}{l}\text { Tripterygium wilfordi } \\
\text { roots extract (Calestrol) }\end{array}$ & $\begin{array}{l}\text { PAMAM dendrimers- } \\
\text { PEG }\end{array}$ & $\begin{array}{l}\text { Particle size, Zeta potential, Surface morphology, } \\
\text { In vitro release, In vitro biostability }\end{array}$ & EDC/NHS technique & {$[30]$} \\
\hline 8 & $\begin{array}{l}\text { Polygonatum } \\
\text { verticillatum rhizome } \\
\text { extract }\end{array}$ & Silver $(\mathrm{Ag})$ & $\begin{array}{l}\text { FT-IR, Morphology and Topography, Crystal } \\
\text { structure, Chemical composition }\end{array}$ & Green Synthesis & {$[37]$} \\
\hline 9 & $\begin{array}{l}\text { Nigella sativa oil } \\
\text { (Thymoquinone) }\end{array}$ & Chitosan & $\begin{array}{l}\text { Particle size, Zeta potential, EE, Endosome } \\
\text { escape study, Morphology, FT-IR, XRD, Thermal } \\
\text { analysis, In vitro release }\end{array}$ & $\begin{array}{l}\text { High-speed } \\
\text { homogenization+ultra } \\
\text { sonication }\end{array}$ & {$[38]$} \\
\hline 10 & $\begin{array}{l}\text { Mentha Longifolia leaf } \\
\text { extract }\end{array}$ & Gold $(\mathrm{Au})$ & FT-IR, Morphology, EDX, PXRD & Green synthesis & [39] \\
\hline 11 & $\begin{array}{l}\text { Cuminum } \\
\text { cyminum L. seed extract }\end{array}$ & Silver & $\begin{array}{l}\text { UV-Vis, Morphology, FT-IR, Crystal structure, } \\
\text { Dimensions, Zeta potential, Size distribution, PDI }\end{array}$ & $\begin{array}{l}\text { Green synthesis } \\
\text { (Biosynthesis) }\end{array}$ & {$[40]$} \\
\hline 12 & Curcumin & $\begin{array}{l}\text { Polyamidoamine } \\
\text { (PAMAM)- } \\
\text { Triphenylphosphoniu } \\
\text { m (TPP) }\end{array}$ & $\begin{array}{l}\text { NMR analysis, particle size, Zeta potensial, } \\
\text { Atomic Force Microscopy, Transmission Electron } \\
\text { Microscopy Analysis }\end{array}$ & & [29] \\
\hline
\end{tabular}


Polymer commonly used as a matrix in a dosage form for its benefit to enhance the properties of the natural ingredients into a desirable level. For example, the preparation of curcumin as a micro and nano sized curcumin and conjugation of curcumin to a polymer could improve curcumin uptake at the cellular level [29]. And preparation of celastrol into a nanopolymeric micelles could improve the hydrophilicity of celastrol and improve its inhibitory effect on retinoblastoma in a mouse xenograft model [30]. Nanocapsules are commonly used as polymeric nanoparticles as it is able to enhance aqueous solubility of lipophilic drugs, control its release, and also increase their bioavailability. Some polymers are sufficiently stable in vitro and long-circulating in vivo and they also showed high cancer cell internalization by Enhanced Penetration Retention (EPR) effect to achieve passive targeting to tumor site [31].

In the manufacture of the powder dosage form with new drug delivery systems, several different types of polymers are used depending on the type of natural ingredients used as active substances. In addition, an evaluation of the dosages was also carried out as listed in table 3.

Natural ingredients that have been made into micro or nano size drugs in these researches are then stored in a powder form to ensure their stability until the following tests are conducted. As most of them were freeze dried and stored in cold temperature. The following evaluations are conducted are common micro and nano powder evaluations. The powder can be evaluated by several methods. The method is used to determine the physicochemical properties of the resulting powder and observe its stability during storage under various conditions. The evaluations that are most commonly carried out are evaluations of morphology, particle size, drug release test, size distribution, zeta potential, average diameter, thermal analysis, crystal structure analysis, and stability test. For powder dosages with a new delivery system, evaluations can only be carried out on polydispersity index and entrapment efficiency.

Micro and nanopowder that has been made are needed to be uniform in particle size so that the size distribution will be good. And that parameter also show whether a method is carried out successfully. A good micro and nanopowder will have a uniform size and even size distribution. Nanoparticles having zeta potential more than $+30 \mathrm{mV}$ and less than $-30 \mathrm{mV}$ are considered good and highly dispersed. Nanoparticles having zeta potential ranging from $+10 \mathrm{mV}$ to- $10 \mathrm{mV}$ are considered neutral [27]. Also, powder with good stability for a long time is considered to be ideal.

\section{Emulsion dosage form}

An emulsion dosage is a mixture of two liquids that do not normally combine, such as oil and water. Emulsions have larger particle sizes than solutions or suspensions. However, emulsion dosages can also cover the taste of the active substance. Moreover, the taste and smell of the oil used as an additive can also be covered. Extracts of natural ingredients tend to have an unpleasant taste. Therefore, the manufacture of pharmaceutical dosages based on extracts in the form of emulsions is quite attractive. Some examples of dosages made are listed in table 4. There are several examples of extracts that are used as emulsion dosages with a new delivery system in the table. Generally, a matrix system is used to realize the drug release system. By making dosages of natural ingredients with new delivery systems, the bioavailability and stability of the dosages can be increased.

Table 4: Dosage forms of emulsions natural medicines

\begin{tabular}{|c|c|c|c|c|c|}
\hline No & Extract & Matrix & Evaluation & Method & Reference \\
\hline 1 & $\begin{array}{l}\text { Nigella sativa } \\
\text { essential oil }\end{array}$ & $\begin{array}{l}\text { Polysorbate } 80- \\
\text { surfactant }\end{array}$ & Stability test, Preparation characterization & Ultrasonication Method & {$[41]$} \\
\hline 2 & $\begin{array}{l}\text { Annona muricata } \\
\text { fruit extract }\end{array}$ & $\begin{array}{l}\text { Stearate Acid- } \\
\text { Poloxamer-Lecithin }\end{array}$ & $\begin{array}{l}\text { Particle size, Zeta potential, Entrapment } \\
\text { efficiency, In vitro release, Optimization, FT IR, FE } \\
\text { SEM }\end{array}$ & $\begin{array}{l}\text { High Pressure } \\
\text { Homogenization } \\
\text { (HPH)+Ultrasonication }\end{array}$ & [42] \\
\hline 3 & Emodin & & $\begin{array}{l}\text { Particle size, Zeta potential, Entrapment } \\
\text { efficiency, Stability test, In vitro release test }\end{array}$ & $\begin{array}{l}\text { High Pressure } \\
\text { Homogenization }(\mathrm{HPH})\end{array}$ & [43] \\
\hline 4 & $\begin{array}{l}\text { Dunaliella salina } \\
\text { extract }\end{array}$ & Gum Arabic & $\begin{array}{l}\text { Loading efficiency, Determination of antioxidant } \\
\text { potential, Test of anticancer potency }\end{array}$ & & {$[44]$} \\
\hline 5 & Plai extract & Chitosan-Quat-188 & Cytotoxicity test, In vitro permeability test & $\begin{array}{l}\text { Low-energy } \\
\text { emulsification }\end{array}$ & [45] \\
\hline 6 & $\begin{array}{l}\text { Psidium guajava } \\
\text { L. }\end{array}$ & $\begin{array}{l}\text { Polycaprolactone- } \\
\text { polysorbate } 80\end{array}$ & $\begin{array}{l}\text { pH, Encapsulation efficiency, DLS, Zeta potential, } \\
\text { NTH, Morphology }\end{array}$ & $\begin{array}{l}\text { Interfacial deposition of } \\
\text { the performed polymer } \\
\text { Method }\end{array}$ & {$[46]$} \\
\hline 7 & $\begin{array}{l}\text { Berberine } \\
\text { (Berberis } \\
\text { vulgaris) }\end{array}$ & $\begin{array}{l}\text { monoolein, poloxamer } \\
407 \text {, polyethylene glycol- } \\
400 \text {, and Transcuto }\end{array}$ & $\begin{array}{l}\text { Particle size, Polydispersity index, Zeta potential, } \\
\text { DSC, Morphology, Shake-flask solubility testing, } \\
\text { Entrapment efficiency, In vitro release }\end{array}$ & Ultrasonication Method & {$[47]$} \\
\hline 8 & $\begin{array}{l}\text { Cannabidiol } \\
\text { (CBD) }\end{array}$ & PLGA & $\begin{array}{l}\text { Morphology, Particle Size, Polydispersity (PDI), } \\
\text { Drug Loading, EE, In vitro Release }\end{array}$ & $\begin{array}{l}\text { Oil-in-water }(\mathrm{O} / \mathrm{W}) \\
\text { emulsion-solvent } \\
\text { evaporation Technique }\end{array}$ & [48] \\
\hline 9 & $\begin{array}{l}\text { Procyanidin-rich } \\
\text { extract (Proc) }\end{array}$ & $\begin{array}{l}\text { Miglyol 812-Epikuron } \\
145 \mathrm{~V}\end{array}$ & $\begin{array}{l}\text { Physicochemical characterization, Nanoparticle } \\
\text { tracking analysis (NTA), Lypophilization and } \\
\text { reconstitution test, Encapsulation efficiency, STEM }\end{array}$ & Solvent transfer method & [49] \\
\hline
\end{tabular}

The preparation that was chosen in these researches are as listed in table 4. Method was selected based on the natural ingredients properties and polymer choice. Besides, dosage form selection is also becoming an important consideration in choosing a suitable method. Natural ingredients with unpleasant smell and taste are suitable to be made into an emulsion because this dosage form could cover tis disadvantages. In these researches, the emulsion was made into nanoemulsion. Nanoemulsions are ultrafine oil-in-water dispersions and have a droplet size range of $10-600 \mathrm{~nm}$. Nanoemulsions are produced by the mixing of two immiscible liquids with or without an emulsifier that contains ultrafine droplets. Nanoemulsions are transparent or opaque, usually a very fluid and extremely fragile system by nature [41]. Previous studies suggested that nanoemulsions can be used as drug carriers, and can impart a long shelf-life to carried drugs for mosquito repellent, antimicrobial, anticancer, larvicidal and insecticidal activities [50].
The emulsion dosage that has been made needs an evaluation process to ensure product quality. Evaluation is carried out using several methods to determine certain parameters. Some examples are particle size evaluation, polydispersity index measurement, thermal analysis, morphological observation, Drug Loading, encapsulation efficiency, lyophilization test, nanoparticle tracking analysis, and in vitro release test. The result of the evaluation should meet the requirements of local government regulation or international regulation. An emulsion dosage form with good stability over the long time, uniform particle size with low polydispersity index, high encapsulation efficiency values, and suitable in vitro release profile considered to be a good emulsion dosage form.

\section{Other dosage forms}

Besides the dosage mentioned above, there are also several other dosages such as micelles, nanofibers, and pellets. Each of these dosages has a new delivery system. By adhering to the matrix 
system, the delivery of natural extracts can be modified. The bioavailability of the natural product dosages can be improved by producing them using a polymer matrix system. Some of these other dosages are listed in table 5.

Table 5: Other dosage forms of natural medicine

\begin{tabular}{|c|c|c|c|c|c|}
\hline No & Extract & Matrix & Evaluation & Method & Reference \\
\hline 1 & Honokiol & Vitamin E TPGS & $\begin{array}{l}\text { In vitro release test, In vitro permeability test, } \\
\text { Pharmacokinetic test }\end{array}$ & $\begin{array}{l}\text { Thin-film } \\
\text { hydration (TFH) }\end{array}$ & {$[51]$} \\
\hline 2 & Honokiol & Rebaudioside A & $\begin{array}{l}\text { Encapsulation efficiency, In vitro release test, } \\
\text { Storage stability test, Pharmacokinetic test, Organ } \\
\text { distribution test Uji }\end{array}$ & $\begin{array}{l}\text { Thin-film } \\
\text { hydration (TFH) }\end{array}$ & {$[52]$} \\
\hline 3 & $\begin{array}{l}\text { Angelica gigas Nakai } \\
\text { extract }\end{array}$ & $\begin{array}{l}\text { Poly (vinylalcohol) (PVA)- } \\
\text { Soluplus (SP) }\end{array}$ & $\begin{array}{l}\text { Solid-state analysis, Wetting and disintegration } \\
\text { tests, characterization, in vitro release profile }\end{array}$ & $\begin{array}{l}\text { Electrospinning } \\
\text { Method }\end{array}$ & [53] \\
\hline 4 & $\begin{array}{l}\text { Hibiscus rosa-sinensis } \\
\text { (HRS) petal extracts }\end{array}$ & Chitosan & $\begin{array}{l}\text { FE-SEM, XRD, ATR-FTIR, EE, Particle size, Particle } \\
\text { size distribution, Zeta potential, In vitro Release }\end{array}$ & $\begin{array}{l}\text { ionic gelation of } \\
\text { chitosan with TPP }\end{array}$ & [54] \\
\hline
\end{tabular}

The preparation that was chosen in these researches are as listed in the table 5. The method chosen depends on what final form the drug will be and is considered through the properties of the natural ingredients. In these researches, natural ingredients are made into nanomicelles, nanofiber, or pellets. Dosage forms are selected based on their intended use. Nanomicelles are nano-sized core-shell micelles formed by amphiphilic block copolymers with hydrophilic and hydrophobic groups that self-assemble in water [55]. Nanometer-sized nanomicelles have many unique advantages as drug carriers, such as high drug loading, wide drug loading range, good stability, long retention time in the body, and biocompatibility with cells and tissues [56]. Nanofiber can be used as a fast-dissolving film for drug application in the oral cavity [53]

After the dosage form was made, it is necessary to evaluate the dosages that have been to ensure product quality. Evaluation is carried out according to each parameter. The evaluations include in vitro release and permeability tests, encapsulation efficiency, storage stability tests, pharmacokinetic tests, organ distribution tests, thermal analysis, particle size distribution, and zeta potential. The result of the evaluation should meet the requirements of local government regulation or international regulation. More parameters meet the requirement, meaning that the dosage form that has been made suitable to be marketed and used. Beside that, the product should be stable for a long time for it to be an ideal dosage form.

\section{Dosage form evaluation}

Evaluation of pharmaceutical products is a process that cannot be separated from the drug development process. Therefore, it is essential to do an evaluation to ensure that a product meets the standard requirements. The preparation of natural product drugs with new delivery systems must also be evaluated to ensure their quality. Dosage forms are considered to be ideal if they are stable for a long time, have the right effect as intended, and meet the parameter values acceptance according to local or international regulation. Different dosage forms will have different acceptance due to excipients and methods used in the production processes. However, some evaluations become critical in certain dosage form evaluation and become a defining parameter whether the product is suitable to be used or not.

\section{In vitro diffusion study}

In vitro diffusion study is an important preliminary evaluation method in determining in vivo drug release [57]. Usually, this test is performed using a Franz Diffusion Cell, in which there is a donor compartment and a receptor compartment. The two compartments use animal skins as membranes, such as rat skin [8] and pigskin [57]

Research conducted by Dhanalakshmi et al. showed that there was a difference in \% diffusion that occurred, which was influenced by the difference in the matrix used. Matrixes that were compared in the research were pectin, sodium alginate, and Carbopol. The test results showed that the patch using Carbopol as the matrix had the highest \% diffused drug, which reached $98 \%$. This value was significant when it was compared to patches using pectin (93\%) and sodium alginate $(89 \%)$ as matrix [8]

\section{Morphology evaluation}

Morphological evaluation is carried out to determine the morphology of the particles in a product. Methods implemented to carry out this evaluation are Scanning Electron Microscopy (SEM) and Transmission Electron Microscopy (TEM). SEM is a method that makes it possible to analyze surface and substrate structures and analyze chemicals of materials with micro or nano dimensions [58] The main difference between SEM and TEM is the resulting image. SEM produces a 3D image of a surface structure, while TEM produces a 2D image.

El Sayeh F. Abou El Ela et al. conducted research on the structure of a fluconazole nanostructure formulation using TEM. The samples used in the research were nanoparticle suspension and the nanoparticle-containing gel of the selected formula with sodium alginate. The test was done on the carbon-coated copper grid [59]. The result showed that fluconazole appeared to be dark and spherical against the bright background, as shown in fig. 3 .

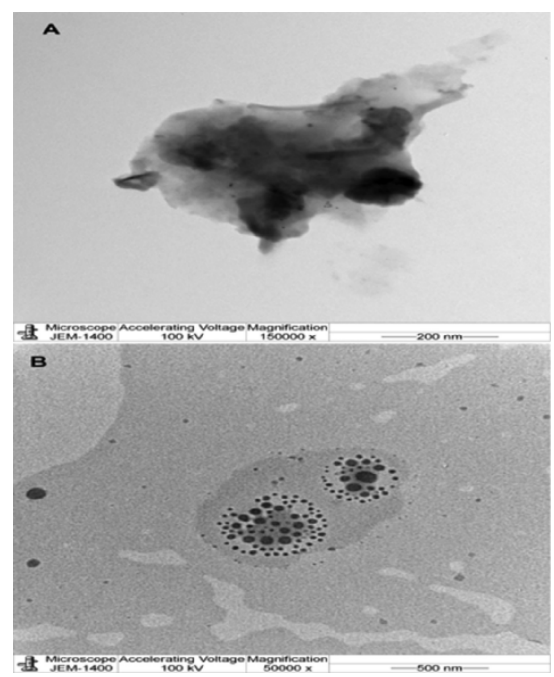

Fig. 3. TEM photographs of (A) FLZ nanoparticle and (B sodium alginate gel formulation containing FLZ nanoparticle [59]

\section{Particle size analysis}

Particle size analysis is carried out to determine the size of the resulting particles. Because the preparations of natural products with new delivery systems are generally made of preparations based on microparticles and nanoparticles, it is necessary to determine the resulting particles' size. Particle size can be determined using several instruments such as TEM [39,59], zeta sizer [22], and SEM.

\section{Polydispersity index (PDI)}

The polydispersity index (PDI) is a measure of the width of size distribution, which is a dimensionless quantity. A small value of PDI indicates a monodispersed population, while a large PDI indicates a broader distribution of particle size[60]. PDI is also used to indicate particle size homogeneity [23]. PDI can be measured using the 
Dynamic Light Scattering Spectroscopy (DLS) method [26], with a zetasizer instrument $[23,31]$. PDI is basically a representation of the distribution of size populations within a given sample. The value of PDI could range from 0.0 (for a perfectly uniform sample with respect to the particle size) to 1.0 (for a highly polydisperse sample with multiple particle size populations). Values of 0.3 and below are most commonly deemed acceptable in practice for polymer-based nanoparticle materials [61]. Furthermore, PDI values ranging from 0.1 to 0.3 indicate a small size distribution, while a PDI value above 0.5 is associated with a larger size distribution [62]

Vasconcelos et al. conducted research on poly-e-caprolactone lipidcore nanocapsules containing lycopene-rich extract from red guava (LEG) stability using PDI values. The measurement was done by DLS using a zetasizer. The PDI values obtained were close to 0.1 and increased very slightly over 7 mo of storage for all samples [46]. Furthermore, PDI values ranging from 0.1 to 0.3 indicate a small size distribution, while a PDI value above 0.5 is associated with a larger size distribution [62]. Therefore, nano LEGs and empty nano presented small size distribution, with good stability over time.

\section{Zeta potential}

Zeta potential is a value that indicates the repulsion forces between particles. Zeta potential is usually measured to estimate the surface charge and the stability of nanomaterials, as changes in these characteristics directly influence the biological activity of a given nanoparticle [63]. Particle with zeta potential values more than $+30 \mathrm{mV}$ and less than- $30 \mathrm{mV}$ are considered highly dispersed and particles with zeta potential values between $+10 \mathrm{mV}$ and $-10 \mathrm{mV}$ are considered neutral [27]. The closer the value to zero, the less dispersed the particle.

Zafar et al. conducted research on Docetaxel and Thymoquinone by Chitosan Grafted Lipid Nanocapsules (CS LNC) using three different Chitosan (CS). Chitosan used for the research were Low Molecular Weight (LMW), Medium Molecular Weight (MMW), and High Molecular Weight (HMW). The samples used for the analysis were Uncoated Lipid Nanocapsules (ULNC), CS Low (CL-LNC), CS Medium (CM-LNC), and CS High (CH-LNC). Zeta potential was found to be$8.17 \pm 0.1 \mathrm{mV}$ (ULNCs), $16.9 \pm 0.5 \mathrm{mV}, 4.94 \pm 0.3 \mathrm{mV}$, and $26.1 \pm 0.5 \mathrm{mV}$ for CL-LNCs, CM-LNCs and CH-LNCs, respectively as shown in fig. 2 [38].

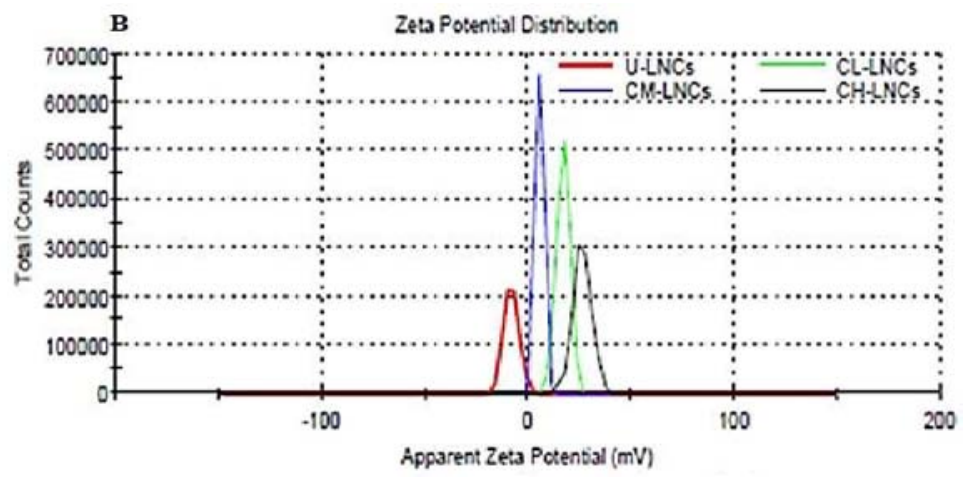

Fig. 4: Effect of different molecular weight chitosan on zeta potential of the LNCs [38]

The change in zeta potential as the particle size increases indicates the different coating on the surface of LNC with different molecular weight CS. CS with a higher degree of deacetylation (DDA) results in greater zeta potential due to the higher charge density of the more deacetylated CS [38]. From this result, nanocapsules can be considered highly dispersed as the molecular weight of chitosan used is increasing.

\section{Entrapment efficiency}

Entrapment Efficiency (EE) is an important parameter in the process of evaluating a product, especially nanocarriers [64]. In addition, EE also needs to be carried out on microcarrier preparations. This method needs to be done to find out how much, in \%, the drug substance is entrapped into the matrix system. The EE value indicates the success rate of a microparticle or nanoparticle preparation. EE measurements can be performed using centrifugation, ultrafiltration, or chromatography methods and analyzed using HPLC or spectrophotometer. The higher entrapment efficiency percentage, the more successful entrapment process of drugs into matrix.

Saleh et al. conducted research to determine the \%EE of Curcuminloaded HSA (CCM-loaded HSA) nanoparticles using the centrifugation method. The supernatant was used to determine the amount of free CCM using a spectrophotometer at $420 \mathrm{~nm}$. The results showed the \%EE of CCM-loaded HAS nanoparticles was 71.3\% [24].

\section{Differential scanning calorimetry (DSC)}

DSC is a thermodynamic technique that measures heat capacity as a function of temperature. DSC has been widely used for protein thermal stability analysis, total conformation, and analysis in the biopharmaceutical industry. In fact, in the beginning, DSC was used as one of the requirements for characterization by regulators [65]. DSC is then also widely used to observe the melting and recrystallization behavior of materials and nanoparticles [18]. In addition, DSC can be used to determine thermodynamic variations associated with changes in shape, such as differences in melting point and of melting enthalpy [20]. These parameters are important in determining drug stability and safety. Based on the result, storage conditions, including container, temperature, light, and humidity, can also be determined.

Chen et al. conducted research on the physical status of AE in SLN using DSC. The scan runs at $40-300{ }^{\circ} \mathrm{C}$ using nitrogen as flush gas [18]. The thermogram of AE, lipid material, mixture, and AE-SLNs was shown in fig. 3. Obviously, the characteristic peaks of $\mathrm{AE}$ crystals and lipid material appeared at $224{ }^{\circ} \mathrm{C}$ and $62{ }^{\circ} \mathrm{C}$, respectively. Meanwhile, the characteristic peaks of $\mathrm{AE}$ and lipid material could also be found in the physical mixture. However, the thermogram of AE-SLNs presented only one characteristic peak at $51{ }^{\circ} \mathrm{C}$. The disappearance of the characteristic peak of AE in the thermogram of SLNs revealed that AE had been encapsulated in the lipid nanoparticles, indicating that $\mathrm{AE}$ existed in amorphous rather than crystal form in nanoparticles [18].

\section{In vitro release test}

In vitro release study is performed to compare the release profile between sample drug and reference drug [66]. In the new drug delivery system, the sample drugs used are microparticle or natural nanoparticle products, and the references used are free drugs that are not within the microparticle or nanoparticle matrix. The methods that can be used in this process are the sink method [21, 38], dialysis bag method [30, 42, 43], and static dialysis method [47]. An ideal drug release profile should be corresponding with the drug target, the need of the patient, and the intended duration of therapy.

$\mathrm{Ge}$ et al. conducted research on G5 dendrimer-celastrol bioconjugates (Ce-G5-P-Ep bioconjugates) in vitro release profile. The method used in this research was the dialysis method. The 
references or positive controls used were free celastrol and PBS containing $20 \%$ ethanol as a medium. PBS was used to imitate the physiological condition and the acidic tumor microenvironment. The test was done for $48 \mathrm{~h}$. The result shown in fig. 4 indicated the release characteristic of celastrol from d Ce-G5-P-Ep bioconjugates displayed a typical two-phase profile containing a burst release within $6 \mathrm{~h}$, then followed by a sustained and slow release over a long time (6-48 h) in PBS with different pH values [30].

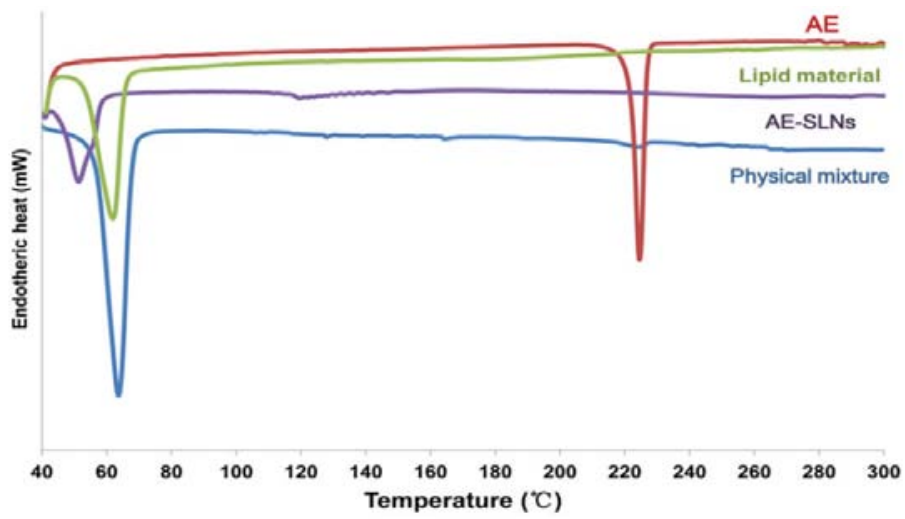

Fig. 5: DSC thermogram of free AE, lipid material, physical mixture and AE-SLNs [18]

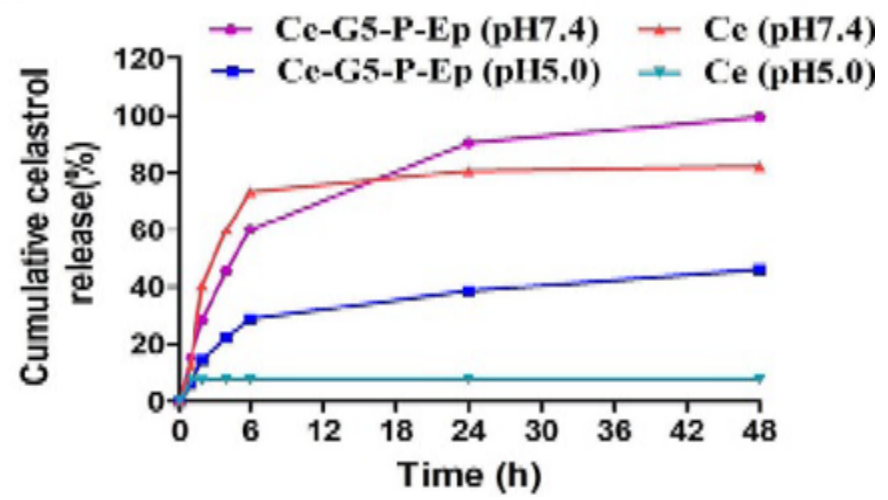

Fig. 6: In vitro cumulative celastrol release from Ce-G5-P-Ep bioconjugates in different pH values of PBS (5.0, 7.4) supplemented with 20\% methanol [30]

\section{MTT assay}

MTT assay a method used to investigate the toxic effects of various materials on various cell lines, including non-cancer and cancer cells [25]. MTT measures cell respiration and the amount of formazan produced is proportional to the number of living cells present in culture. An increase or decrease in cell number results in a concomitant change in the amount of formazan formed, indicating the degree of cytotoxicity caused by the drug (Florento, 2012). The final result of the test is in the form of $I C_{50}$. The lower the value, the more cytotoxic the drugs tested are. Cell analysis was done using a flow cytometry machine and counted using the following formula [25]:

$$
\text { Cell Viability }(\%)=\frac{\text { Sample }}{\text { Control }} \mathrm{X} 100
$$

Every anticancer drug development should do this evaluation to make sure the drug has anti-cancer activity against the target cancer cells and is not toxic to healthy cells. One of the researches done by Liu et al., gold nanoparticles containing Allium sativum L. leaf aqueous extract are tested to find out its toxic effects against human colon cancer and normal cell line. There were 5 sample groups. Normal cell line (HUVEC), Colorectal adenocarcinoma (HT-29), Colorectal carcinoma (HCT 116), Ileocecal colorectal adenocarcinoma (HCT-8 [HRT-18]), and Burkitt's lymphoma (Ramos.2G6.4C10). he result shows $\mathrm{Au}$ nanoparticles had appropriate anti-colon cancer activities dose-dependently against HT-29, HCT 116, HCT-8 [HRT-18], and Ramos.2G6.4C10 cell lines without any cytotoxicity on the normal cell line (HUVEC) [25].
The dosage forms of anticancer drugs in chemotherapy are generally in the form of tablets and injections. However, these preparations in certain conditions have limitations and side effects that are uncomfortable for the patient, so the search for new anticancer active compounds is necessary. In order to develop anticancer drugs from natural ingredients, the preparations can be made into new dosage forms, such as some of the above preparations, which have also used several plant extracts as active substances.

Each dosage form preparation has to go through a different evaluation. Because many natural products are made into micro or nanoparticles to achieve their anti-cancer activity, in order to make the dosage form up to standard, the evaluations written above are necessary.

\section{CONCLUSION}

Cancer is a non-infectious disease that is growing rapidly. Cancer can be treated with various drugs, both synthetic and natural, and chemotherapy. Certain natural products like extract, fraction, and isolates shows their promising anti-cancer activity. To achieve this, the various method can be used to make natural ingredients into suitable dosage form such as patch, suspension, emulsion, powder, nanomicelles, nanofiber, and pellet. Natural ingredients can be made into micro and nano-size drugs and delivered using a new drug delivery system to enhance their solubility and bioavailability. To make this, polymers are used as a matrix in the system. Each dosage form then evaluated with a different method to ensure whether the manufacturing method was carried out successfully and determining 
their stability and other properties and also to make sure their anticancer activity. Evaluation needed to be done according to the government or international regulation. Some of the evaluations are In vitro Diffusion Study, Morphology Evaluation, Particle Size Analysis, Polydispersity Index (PDI), Zeta Potential, Entrapment Efficiency, Differential scanning calorimetry (DSC), In vitro Release Test, and MTT Assay. These evaluations determine whether the dosage forms are ideal and achieve their target activity.

\section{ACKNOWLEDGMENT}

The author thanks the Directorate of Research and Community Engagement of Universitas Padjadjaran for the funding.

\section{AUTHORS CONTRIBUTIONS}

All the authors have contributed equally.

\section{CONFLICT OF INTERESTS}

Declared none

\section{REFERENCES}

1. Tiwari G, Tiwari R, Sriwastawa B, Bhati L, Pandey S, Pandey P, Bannerjee SK. Drug delivery systems: an updated review. Int J Pharm Investig. 2012;2(1):2-11. doi: 10.4103/2230973X.96920, PMID 23071954.

2. Rojo J, Sousa Herves A, Mascaraque A. 1.24-perspectives of carbohydrates in drug discovery. In: Oxford: Elsevier; 2017. p. 577-610. Available from: https://www.sciencedirect.com [Last 19 Apr 2021].

3. Atanasov AG, Waltenberger B, Pferschy Wenzig EM, Linder T, Wawrosch C, Uhrin P, et al. Discovery and resupply of pharmacologically active plant-derived natural products: a review. Biotechnol Adv. 2015;33(8):1582-614. doi: 10.1016/j.biotechadv.2015.08.001, PMID 26281720.

4. Atanasov AG, Zotchev SB, Dirsch VM, International Natural Product Sciences Taskforce, Supuran CT. Natural products in drug discovery: advances and opportunities. Nat Rev Drug Discov. 2021;20(3):200-16. doi: 10.1038/s41573-020-00114z, PMID 33510482.

5. Sahoo CK, Reddy GS, Vojjala A, Reddy BV. Bioavailability enhancement for poorly soluble drugs: a review. IIJS. 2018. p. 1-6.

6. Abuzar SM, Hyun SM, Kim JH, Park HJ, Kim MS, Park JS, Hwang SJ. Enhancing the solubility and bioavailability of poorly watersoluble drugs using supercritical antisolvent (SAS) process. Int J Pharm. 2018;538(1-2):1-13. doi: 10.1016/j.ijpharm. 2017.12.041, PMID 29278733.

7. Rizvi SAA, Saleh AM. Applications of nanoparticle systems in drug delivery technology. Saudi Pharm J. 2018;26(1):64-70. doi: 10.1016/j.jsps.2017.10.012, PMID 29379334.

8. Dhanalakshmi S, Harikrishnan N, Devi M, Keerthana V, Vijayalakshmi. Fabrication and evaluation of herbal transdermal flim from hibiscus rosa sinensis. Int J Curr Pharm Sci. 2019;11(5):101-5. doi: 10.22159/ijcpr.2019v11i5.35716.

9. Karpagavalli L, Mahaeswaran A, Praveena P, Sharmila S, Meena B. Formulation and evaluation of transdermal patches of curcumin. Int J Novel Trends Pharm Sci. 2017;7(1):22-6.

10. Saleem MN, Idris M. Formulation design and development of a Unani transdermal patch for antiemetic therapy and its pharmaceutical evaluation. Scientifica. 2016;2016:7602347. doi: 10.1155/2016/7602347, PMID 27403377.

11. Savula J, Krishna MKS, Anwesh H, Prashanth K. Formulation and evaluation of herbal transdermal patches. World J Pharm Res. 2017;6(13):365-74.

12. Ansel HC, Allen LV, Popovich NG. Pharmauceutical dosage forms and drug delivery system. Philadelphia: Lippincott Williams and Wilkins; 1999.

13. Ubaidulla U, Reddy MVS, Ruckmani K, Ahmad FJ, Khar RK. Transdermal therapeutic system of carvedilol: effect of hydrophilic and hydrophobic matrix on in vitro and in vivo characteristics. AAPS PharmSciTech. 2007;8(1):2. doi: 10.1208/pt0801002, PMID 17408218.

14. Patel M, Patel B, Patel R, Jayvadan P, Bharadia P, Patel M. Carbopol: A versatile polymer. Drug Deliv Technol. 2006;3(6):32-43.
15. Shabbir M, Ali S, Raza M, Sharif A, Akhtar FM, Manan A, Fazli AR, Younas N, Manzoor I. Effect of hydrophilic and hydrophobic polymer on in vitro dissolution and permeation of bisoprolol fumarate through transdermal patch. Acta Pol Pharm. 2017;74(1):187-97. PMID 29474775.

16. Ilhan Ayisigi E, Ulucan F, Saygili E, Saglam Metiner P, Gulce-Iz S, Yesil Celiktas O. Nano-vesicular formulation of propolis and cytotoxic effects in a 3D spheroid model of lung cancer. J Sci Food Agric. 2020;100(8):3525-35. doi: 10.1002/jsfa.10400, PMID 32239766.

17. Baranei M, Taheri RA, Tirgar M, Saeidi A, Oroojalian F, Uzun L, Asefnejad A, Wurm FR, Goodarzi V. Anticancer effect of green tea extract (GTE)-Loaded pH-responsive niosome coated with PEG against different cell lines. Mater Today Commun. 2021;26. doi: 10.1016/j.mtcomm.2020.101751, PMID 101751.

18. Chen R, Wang S, Zhang J, Chen M, Wang Y. Aloe-emodin loaded solid lipid nanoparticles: formulation design and in vitro anticancer study. Drug Deliv. 2015;22(5):666-74. doi: 10.3109/10717544.2014.882446, PMID 24512431.

19. Donoso Quezada J, Guajardo Flores D, Gonzalez Valdez J. Exosomes as nanocarriers for the delivery of bioactive compounds from black bean extract with antiproliferative activity in cancer cell lines. Mater Today Proc. 2019;13:362-9. doi: 10.1016/j.matpr.2019.03.166.

20. Shi F, Zhao JH, Liu Y, Wang Z, Zhang YT, Feng NP. Preparation and characterization of solid lipid nanoparticles loaded with frankincense and myrrh oil. Int J Nanomed. 2012;7:2033-43. doi: $10.2147 /$ IJN.S30085, PMID 22619540.

21. Lee SY, Lee JJ, Nam S, Kang WS, Yoon IS, Cho HJ. Fabrication of polymer matrix-free nanocomposites based on Angelica gigas Nakai extract and their application to breast cancer therapy. Colloids Surf B Biointerfaces. 2017;159:781-90. doi: 10.1016/j.colsurfb.2017.08.040, PMID 28886514.

22. Wang Y, Yu H, Wang S, Gai C, Cui X, Xu Z, Li W, Zhang W. Targeted delivery of quercetin by nanoparticles based on chitosan sensitizing paclitaxel-resistant lung cancer cells to paclitaxel. Mater Sci Eng C Mater Biol Appl. 2021;119:111442. doi: $10.1016 /$ j.msec.2020.111442.

23. Sabry S, El Hakim Ramadan A, Abd Elghany M, Okda T, Hasan A. Formulation, characterization, and evaluation of the anti-tumor activity of nanosized galangin loaded niosomes on chemically induced hepatocellular carcinoma in rats. J Drug Deliv Sci Technol. 2021;61. doi: 10.1016/j.jddst.2020.102163, PMID 102163.

24. Saleh T, Soudi T, Shojaosadati SA. Aptamer functionalized curcumin-loaded human serum albumin (HSA) nanoparticles for targeted delivery to HER-2 positive breast cancer cells. Int J Biol Macromol. 2019;130:109-16. doi: 10.1016/j.ijbiomac.2019.02.129, PMID 30802519.

25. Liu Q, Wu F, Chen Y, Alrashood ST, Alharbi SA. Anti-human colon cancer properties of a novel chemotherapeutic supplement formulated by gold nanoparticles containing Allium sativum L. leaf aqueous extract and investigation of its cytotoxicity and antioxidant activities. Arab J Chem. 2021;14(4). doi: 10.1016/j.arabjc.2021.103039, PMID 103039.

26. Mughees M, Wajid S, Samim M. Cytotoxic potential of artemisia absinthium extract loaded polymeric nanoparticles against breast cancer cells: insight into the protein targets. Int J Pharm. 2020;586:119583. doi: 10.1016/j.ijpharm.2020.119583.

27. Barhoum A, Garcia Betancourt ML, Rahier H, Van Assche G. Physicochemical characterization of nanomaterials: polymorph, composition, wettability, and thermal stability. In: Barhoum A, Makhlouf ASH, editors. Elsevier; 2018. p. 255-78. Available from: https://www.sciencedirect.com. [Last accessed on 06 Aug 2021].

28. Meena J, Gupta A, Ahuja R, Singh M, Bhaskar S, Panda AK. Inorganic nanoparticles for natural product delivery: a review. Environ Chem Lett. 2020;18(6):2107-18. doi: 10.1007/s10311020-01061-2.

29. Kianamiri S, Dinari A, Sadeghizadeh M, Rezaei M, Daraei B, Bahsoun NE-H, Nomani A. Mitochondria-targeted polyamidoamine dendrimer-curcumin construct for hepatocellular cancer treatment. Mol Pharm. 2020;17(12):4483-98. doi 10.1021/acs.molpharmaceut.0c00566, PMID 33205974.

30. Ge P, Niu B, Wu Y, Xu W, Li M, Sun H, Zhou H, Zhang X, Xie J. Enhanced cancer therapy of celastrol in vitro and in vivo by smart 
dendrimers delivery with specificity and biosafety. Chem Eng J. 2020;383. doi: 10.1016/j.cej.2019.123228, PMID 123228.

31. Haggag YA, Ibrahim RR, Hafiz AA. Design, formulation and in vivo evaluation of novel honokiol-loaded pegylated PLGA nanocapsules for treatment of breast cancer. IJN 2020;15:1625-42. doi: 10.2147/IJN.S241428.

32. Gera M, Kim N, Ghosh M, Sharma N, Huynh DL, Chandimali N, Koh H, Zhang JJ, Kang TY, Park YH, Kwon T, Jeong DK. Synthesis and evaluation of the antiproliferative efficacy of BRM270 phytocomposite nanoparticles against human hepatoma cancer cell lines. Mater Sci Eng C Mater Biol Appl. 2019;97:166-76. doi: 10.1016/j.msec.2018.11.055, PMID 30678901.

33. Chen J, Li Y, Fang G, Cao Z, Shang Y, Alfarraj S, Ali Alharbi S, Li J, Yang S, Duan X. Green synthesis, characterization, cytotoxicity, antioxidant, and anti-human ovarian cancer activities of Curcumae kwangsiensis leaf aqueous extract greensynthesized gold nanoparticles. Arab J Chem. 2021;14(3). doi: 10.1016/j.arabjc.2021.103000, PMID 103000.

34. Li Y, Li X, Lu Y, Chaurasiya B, Mi G, Shi D, Chen D, Webster TJ, $\mathrm{Tu}$ J, Shen Y. Co-delivery of Poria cocos extract and doxorubicin as an 'all-in-one' nanocarrier to combat breast cancer multidrug resistance during chemotherapy. Nanomed Nanotechnol Biol Med. 2020;23. doi: 10.1016/j.nano.2019.102095, PMID 102095.

35. Pillai SC, Borah A, Jindal A, Jacob EM, Yamamoto Y, Kumar DS. BioPerine encapsulated nanoformulation for overcoming drugresistant breast cancers. Asian J Pharm Sci. 2020;15(6):701-12. doi: 10.1016/j.ajps.2020.04.001, PMID 33363626.

36. Shah HS, Usman F, Ashfaq Khan M, Khalil R, Ul-Haq Z, Mushtaq A, Qaiser R, Iqbal J. Preparation and characterization of anticancer niosomal withaferin-a formulation for improved delivery to cancer cells: in vitro, in vivo, and in silico evaluation. J Drug Deliv Sci Technol. 2020;59. doi: 10.1016/j.jddst.2020.101863, PMID 101863.

37. Pathak M, Pathak P, Rimac H, Grishina M, Bagale U, Kumar V, Rahul Majee, Vladimir Potemkin, Verma A. Attenuation of hepatic and breast cancer cells by Polygonatum verticillatum embedded silver nanoparticles. Biocatal Agric Biotechnol. 2020;30. doi: 10.1016/j.bcab.2020.101863, PMID 101863.

38. Zafar S, Akhter S, Ahmad I, Hafeez Z, Alam Rizvi MM, Jain GK, Ahmad FJ. Improved chemotherapeutic efficacy against resistant human breast cancer cells with co-delivery of docetaxel and thymoquinone by chitosan grafted lipid nanocapsules: formulation optimization, in vitro and in vivo studies. Colloids Surf B Biointerfaces. 2020;186:110603. doi: 10.1016/j.colsurfb.2019.110603.

39. Li S, Al-Misned FA, El-Serehy HA, Yang L. Green synthesis of gold nanoparticles using aqueous extract of Mentha longifolia leaf and investigation of its anti-human breast carcinoma properties in the in vitro condition. Arab J Chem. 2021;14(2). doi: 10.1016/j.arabjc.2020.102931, PMID 102931.

40. Dinparvar S, Bagirova M, Allahverdiyev AM, Abamor ES, Safarov T, Aydogdu M, Aktas D. A nanotechnology-based new approach in the treatment of breast cancer: biosynthesized silver nanoparticles using cuminum cyminum L. seed extract. J Photochem Photobiol B. 2020;208:111902. doi: 10.1016/j.jphotobiol.2020.111902.

41. Periasamy VS, Athinarayanan J, Alshatwi AA. Anticancer activity of an ultrasonic nanoemulsion formulation of Nigella sativa L. essential oil on human breast cancer cells. Ultrason Sonochem. 2016;31(31):449-55 10.1016/j.ultsonch.2016.01.035, PMID 26964971.

42. Sabapati M, Palei NN, CK AK, Molakpogu RB. Solid lipid nanoparticles of Annona muricata fruit extract: formulation, optimization and in vitro cytotoxicity studies. Drug Dev Ind Pharm. 2019;45(4):577-86 10.1080/03639045.2019.1569027, PMID 30663427

43. Wang S, Chen T, Chen R, Hu Y, Chen M, Wang Y. Emodin loaded solid lipid nanoparticles: preparation, characterization and antitumor activity studies. Int J Pharm. 2012;430(1-2):238-46. doi: 10.1016/j.ijpharm.2012.03.027, PMID 22465546.

44. Zamani H, Rastegari B, Varamini M. Antioxidant and anticancer activity of Dunaliella salina extract and oral drug delivery potential via nano-based formulations of gum arabic coated magnetite nanoparticles. J Drug Deliv Sci Technol. 2019 Dec 1;54. doi: 10.1016/j.jddst.2019.101278, PMID 101278.

45. Luesakul U, Puthong S, Sansanaphongpricha K, Muangsin N. Quaternized chitosan-coated nanoemulsions: A novel platform for improving the stability, anti-inflammatory, anti-cancer and transdermal properties of plai extract. Carbohydr Polym. 2020;230:115625. doi: 10.1016/j.carbpol.2019.115625.

46. Vasconcelos AG, Valim MO, Amorim AGN, do Amaral CP, de Almeida MP, Borges TKS, Socodato R, Portugal CC, Brand GD, Mattos JSC, Relvas J, Placido A, Eaton $P$, Ramos DAR, Kuckelhaus SAS, Leite JRSA. Cytotoxic activity of poly- $\varepsilon$ caprolactone lipid-core nanocapsules loaded with lycopenerich extract from red guava (Psidium guajava L.) on breast cancer cells. Food Res Int. 2020;136. doi: 10.1016/j.foodres.2020.109548, PMID 109548.

47. Loo YS, Madheswaran T, Rajendran R, Bose RJC. Encapsulation of berberine into liquid crystalline nanoparticles to enhance its solubility and anticancer activity in MCF7 human breast cancer cells. J Drug Deliv Sci Technol. 2020;57. doi: 10.1016/j.jddst.2020.101756, PMID 101756.

48. Fraguas Sanchez AI, Fernandez Carballido A, Simancas Herbada R Martin Sabroso C, Torres Suarez AI. CBD loaded microparticles as a potential formulation to improve paclitaxel and doxorubicin-based chemotherapy in breast cancer. Int J Pharm. 2020;574:118916. doi: 10.1016/j.jpharm.2019.118916.

49. Cerda Opazo P, Gotteland M, Oyarzun Ampuero FA, Garcia L. Design, development and evaluation of nanoemulsion containing avocado peel extract with anticancer potential: A novel biological active ingredient to enrich food. Food Hydrocoll. 2021;111. doi: 10.1016/j.foodhyd.2020.106370, PMID 106370.

50. Pant M, Dubey S, Patanjali PK, Naik SN, Sharma S. Insecticida activity of eucalyptus oil nanoemulsion with Karanja and jatropha aqueous filtrates. Int Biodeterior Biodegrad. 2014;91:119-27. doi: 10.1016/j.ibiod.2013.11.019.

51. Godugu C, Doddapaneni R, Singh M. Honokiol nanomicellar formulation produced increased oral bioavailability and anticancer effects in triple negative breast cancer (TNBC). Colloids Surf B Biointerfaces. 2017:153:208-19. doi: 10.1016/j.colsurfb.2017.01.038, PMID 28249200.

52. Wang J, Yang H, Li Q, Wu X, Di G, Fan J, Wei D, Guo C. Novel nanomicelles based on rebaudioside $A$ : A potential nanoplatform for oral delivery of honokiol with enhanced oral bioavailability and antitumor activity. Int J Pharm. 2020;590:119899. doi: 10.1016/j.ijpharm.2020.119899.

53. Nam S, Lee JJ, Lee SY, Jeong JY, Kang WS, Cho HJ. Angelica gigas Nakai extract-loaded fast-dissolving nanofiber based on poly(vinyl alcohol) and soluplus for oral cancer therapy. Int J Pharm. 2017;526(1-2):225-34. 10.1016/j.ijpharm.2017.05.004, PMID 28478278.

54. Nayak D, Minz AP, Ashe S, Rauta PR, Kumari M, Chopra P, Nayak B. Synergistic combination of antioxidants, silver nanoparticles and chitosan in a nanoparticle based formulation: characterization and cytotoxic effect on MCF-7 breast cancer cell lines. J Colloid Interface Sci. 2016;470:14252. doi: 10.1016/j.jcis.2016.02.043, PMID 26939078.

55. Zhang $\mathrm{F}$, Li R, Yan M, Li Q, Li Y, Wu X. Ultra-small nanocomplexes based on polyvinylpyrrolidone K-17PF: A potential nanoplatform for the ocular delivery of kaempferol. Eur J Pharm Sci. 2020;147:105289. doi: 10.1016/j.ejps.2020.105289.

56. Mohammad IS, Teng C, Chaurasiya B, Yin L, Wu C, He W. Drugdelivering-drug approach-based codelivery of paclitaxel and disulfiram for treating multidrug-resistant cancer. Int J Pharm. 2019;557:304-13. doi: 10.1016/j.ijpharm.2018.12.067, PMID 30599232.

57. Ravikumar R, Ganesh M, Senthil V, Ramesh YV, Jakki SL, Choi EY. Tetrahydro curcumin loaded PCL-PEG electrospun transdermal nanofiber patch: preparation, characterization, and in vitro diffusion evaluations. J Drug Deliv Sci Technol. 2018;44:342-8. doi: 10.1016/j.jddst.2018.01.016.

58. Golinejad S, Mirjalili MH. Fast and cost-effective preparation of plant cells for scanning electron microscopy (SEM) analysis. Anal Biochem. 2020;609:113920. doi: 10.1016/j.ab.2020.113920. 
59. El Sayeh F Abou El Ela A, Abbas Ibrahim M, Alqahtani Y, Almomen A, Sfouq Aleanizy F. Fluconazole nanoparticles prepared by antisolvent precipitation technique: physicochemical, in vitro, ex vivo and in vivo ocular evaluation. Saudi Pharm J. 2021;29(6):576-85. doi: 10.1016/j.jsps.2021.04.018, PMID 34194264.

60. Sinha P, Srivastava N, Rai VK, Mishra R, Ajayakumar PV, Yadav NP. A novel approach for dermal controlled release of salicylic acid for improved anti-inflammatory action: combination of hydrophilic-lipophilic balance and response surface methodology. J Drug Deliv Sci Technol. 2019;52:870-84. doi: 10.1016/j.jddst.2019.06.007.

61. Danaei M, Dehghankhold M, Ataei S, Hasanzadeh Davarani F, Javanmard R, Dokhani A, Khorasani S, Mozafari MR. Impact of particle size and polydispersity index on the clinical applications of lipidic nanocarrier systems. Pharmaceutics. 2018;10(2):57. doi: 10.3390/pharmaceutics10020057, PMID 29783687.

62. Gonzalez Reza RM, Quintanar Guerrero D, Del Real Lopez A, Pinon Segundo E, Zambrano Zaragoza ML. Effect of sucrose concentration and $\mathrm{pH}$ onto the physical stability of $\beta$-carotene nanocapsules. LWT. 2018;90:354-61. doi: 10.1016/j.lwt.2017.12.044.

63. Sizochenko N, Mikolajczyk A, Syzochenko M, Puzyn T, Leszczynski J. Zeta potentials ( $\zeta$ ) of metal oxide nanoparticles: A meta-analysis of experimental data and a predictive neural networks modeling. NanoImpact. 2021;22. doi 10.1016/j.impact.2021.100317:, 100317PMID 100317.

64. Lv Y, He H, Qi J, Lu Y, Zhao W, Dong X, Wu W. Visual validation of the measurement of entrapment efficiency of drug nanocarriers. Int J Pharm. 2018;547(1-2):395-403. doi: 10.1016/j.ijpharm.2018.06.025, PMID 29894757.

65. Wen J, Arthur K, Chemmalil L, Muzammil S, Gabrielson J, Jiang Y. Applications of differential scanning calorimetry for thermal stability analysis of proteins: qualification of DSC. J Pharm Sci. 2012;101(3):955-64. doi: 10.1002/jps.22820, PMID 22147423

66. Pleguezuelos Villa M, Merino Sanjuan M, Hernandez MJ, Nacher A, Peris D, Hidalgo I, Soler L, Sallan M, Merino V. Relationship between rheological properties, in vitro release and in vivo equivalency of topical formulations of diclofenac. Int J Pharm. 2019;572:118755. doi: 10.1016/j.ijpharm.2019.118755. 